\title{
Simultaneous occurrence of pulmonary tuberculosis and carcinomatous lymphangitis
}

\author{
Ocorrência simultânea de tuberculose pulmonar \\ e linfangite carcinomatosa
}

\author{
Felipe Francisco Tuon ${ }^{1}$, Karina T. Miyaji ${ }^{1}$, Paula Marques de Vidal', \\ Luiz Fernando Ferraz da Silva ${ }^{2}$, Adriana Kono ${ }^{1}$ \\ and Francisco Oscar de Siqueira Franca ${ }^{1}$
}

\begin{abstract}
Tuberculosis is an important cause of mortality due to its high prevalence, considering that one third of the world's population is infected with the tuberculosis bacillus. We report the first case of carcinomatous lymphangitis associated with active pulmonary tuberculosis. Carcinomatous lymphangitis is a rare event that may be confounded with tuberculosis because of its radiographic and clinical characteristics.
\end{abstract}

Key-words: Tuberculosis. Carcinomatous lymphangitis. Miliary tuberculosis. Lung. Cancer.

\section{RESUMO}

Tuberculose é uma causa importante de mortalidade devido a sua alta prevalência, uma vez que um terço da população mundial encontra-se infectada com o bacilo da tuberculose. Nós relatamos o primeiro caso de linfangite carcinomatosa associada à tuberculose pulmonar ativa. A linfangite carcinomatosa é um evento raro que pode ser confundida com tuberculose pelos aspectos clínicos e radiológicos.

Palavras-chaves: Tuberculose. Linfangite carcinomatosa. Tuberculose miliar. Pulmão. Cancer.

Tuberculosis is among the top ten causes of global mortality and the World Health Organization has estimated that there are 10 million cases/year. Almost one third of the world's population is infected with the tuberculosis bacillus ${ }^{1}$. Tuberculosis is associated with cellular immune dysfunction, and this can be observed in three very frequent situations today: cancer, advanced age and AIDS. Thus, continuous tuberculosis surveillance must be emphasized. Carcinomatous lymphangitis (CL) is a rare event characterized by lung vessel infiltration with metastatic cells ${ }^{2}$. The common sources of CL are stomach, breast, prostate, pancreas and thyroid cancer. CL from ovarian cancer is the rarest event, occurring in less than $1 \%$ of CL cases ${ }^{4}$. Although some published reports have demonstrated CL as a differential diagnosis of pulmonary tuberculosis, some radiographic characteristics may be similar ${ }^{5}$. We report the first case of ovarian CL associated with active pulmonary tuberculosis.

\section{CASE REPORT}

A 45-year-old female patient was admitted in July 2005 with dyspnea, cough with bloody sputum, fever and night sweating, anorexia and weight loss of five kilograms in two months. Three months before admission she had undergone hysterectomy for a reason that was unknown at that moment. No other significant sign or symptom was observed. An interstitial and alveolar infiltrate was identified in both lungs on chest x-ray. Three sputum samples were negative for acid-fast bacilli. A tuberculin skin test yielded anergy. A chest CT scan demonstrated significant bilateral interstitial infiltrate, without other findings. The patient underwent bronchoscopy with biopsy, from which the anatomopathological findings were compatible with CL (Figure 1). The immunohistochemical pattern revealed an ovarian origin. The anatomopathological examination from the

\footnotetext{
1. Departamento de Moléstias Infecciosas e Parasitárias, Faculdade de Medicina, Universidade de São Paulo, São Paulo, SP. 2. Departamento de Anatomia Patológica, Faculdade de Medicina, Universidade de São Paulo, São Paulo, SP.

Address to: Dr. Felipe Francisco Tuon. ICHC. Avenida Dr. Eneas de Carvalho Aguiar $2554^{\circ}$ andar, sala 4028, Cerqueira Cesar, 05403-010 São Paulo, SP, Brasil

Tel: 5511 3069-6530; Fax: 5511 3069-7508

e-mail: ffbt@pop.com.br

Recebido para publicação em 3/5/2006

Aceito em17/1/2007
} 


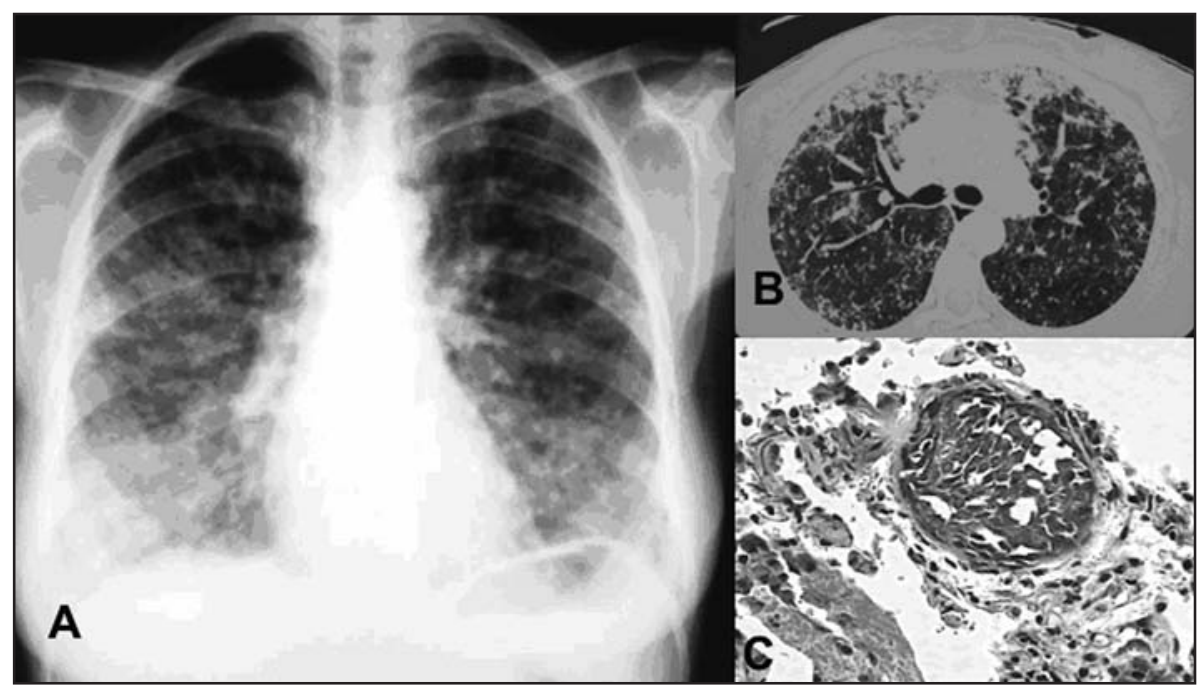

Figure 1 - Patient with pulmonary tuberculosis and associated carcinomatous lymphangitis. A - Chest $X$-ray with interstitial infiltrate; $B$ - Chest computed tomography; $C$-Anatomopathological examination in hematoxylin-eosin showing a small vessel with carcinomatous lymphangitis.

previous hysterectomy was retrieved and the result confirmed ovarian cancer. Chemotherapy with paclitaxel and carboplatin in association with dexamethasone was started. Three weeks after starting the chemotherapy, a culture from bronchoalveolar lavage in Lowestein-Jensen yielded Mycobacterium tuberculosis. Rifampin, isoniazid and pyrazinamide were started and the patient successfully completed the tuberculosis treatment six months later. She now presents complete clinical remission from ovarian cancer and CL.

\section{DISCUSSION}

To our knowledge, no cases of simultaneous CL and pulmonary tuberculosis have been described. The typical radiographic appearance of CL on CT scans is septal thickening. Nevertheless, the radiographic findings may resemble tuberculosis and there are several descriptions of patients undergoing treatment for suspected tuberculosis among whom there was disease progression, with the discovery of CL only on biopsy ${ }^{34}$.

Tuberculosis continues to be a challenge in developed and underdeveloped countries. Radiographic and clinical findings of pulmonary tuberculosis present low specificity and a huge range of differential diagnoses, particularlywith miliary tuberculosis, with findings of interstitial lung infiltrate that frequently requires bronchoalveolar lavage and biopsy in order to ascertain the etiological diagnosis.

\section{ACKNOWLEDGMENTS}

We thank Juliana Mori for excellent picture \& photo preparation.

\section{REFERENCES}

1. Borgdorff MW, Floyd K, Broekmans JF. Interventions to reduce tuberculosis mortality and transmission in low- and middle-income countries. Bulletin of World Health Organization 80: 217-227, 2002.

2. Bruce DM, Heys SD, Eremin 0. Lymphangitis carcinomatosa: a literature review. Journal of Royal College of Surgeons of Edinburgh 41: 7-13, 1996.

3. Dzhurov G. Case of primary pulmonary carcinoma with bilateral carcinomatous lymphangitis erroneously diagnosed as chronic disseminated pulmonary tuberculosis. Suvremenna Meditsina 7: 97-100, 1956.

4. Kerr VE, Cadman E. Pulmonary metastases in ovarian cancer. Analysis of 357 patients. Cancer 56: 1209-1213, 1985.

5. Marchiori E, Kavakama J, Sales A. Linfangite carcinomatosa: correlaçäo da tomografia computadorizada de alta resoluçäo com a anatomopatologia. Revista da Imagem 22: 1-5, 2000.

6. Ueda S, Ooka H, Yamaguchi M, Hayashi H, Okayasu T. Case of pulmonary metastasis of ovarian cancer erroneously diagnosed and treated as pulmonary tuberculosis for a long time. Nihon Kyobu Shikkan Gakkai Zasshi 11: 684-687, 1973. 